\title{
Influence of Corporate Taxation on the Financial Leverage of Czech, Polishand Russian Companies
}

\author{
Irena Jindrichovska \\ Doctor of Economic Sciences \\ ORCID \\ E-mail: irena.jindrichovska@map.cz
}

Metropolitan University,Prague, the Czech Republic

\section{Viacheslav Moskalchuk}

Senior analyst

$\underline{\text { ORCID }}$

E-mail: moskalchukvs@gmail.com

The Network of Cosmetology Clinics, Moscow, Russia

Journal of Corporate Finance Research, Vol. 13, No. 3, pp. 61-70 (2019)

DOI: https://doi.org/10.17323/j.jcfr.2073-0438.13.3.2019.61-70

Received 8 April 2019 | Peer-reviewed 5 June 2019 | Accepted 3 September 2019 


\section{Influence of Corporate Taxation on the Financial Leverage of Czech, Polishand Russian Companies}

\section{Abstract}

This article aims to compare and contrast the available empirical evidence concerning the capital structure of Polish, Czech and Russian companies. This is an intriguing research area due to the fact that the Czech and Polish economies began their transition to the market economy contemporaneously with Russia, and so along with other cultural and historical parallels, the data is comparable.

We compare data from a selection of large companies from the selected territories and investigate whether effective tax rate is significant determinant of capital structure. The selected sample is comprised of 69 companies (50 from Russia, 9 from Poland, and 10 from Czech Republic), using data over a period of fourteen years. We perform a regression analysis and interpret the results using theoretical knowledge as articulated in the academic literature. The dependent variable in all tested regressions is financial leverage, calculated as the ratio of the sum of short-term and long-term debts to the sum of short-term and long-term assets. Other variables evaluated include interest coverage ratio, the level of company tangibility, and the cost of debt. This set of input values was uploaded from the Bloomberg database.

Our results indicate that taxation does have determining effect on the choice of a certain level of leverage. Moreover, the effective tax rate represents the most important factor in determining the model of capital structure utilised by large companies in each country studied. We establish the dependence of capital structure models on the level of corporate tax applied in each country and identify a set of additional determinants which play a significant role.

This paper's novelty may be summarised as representing an advanced understanding of specific aspects of influence of the corporate taxation on the capital structure of companies in Russia and other economies of the former Eastern Bloc. This paper shines a new light on the subject area by extending the duration of the studied data beyond previous research, to fourteen years. As such, in this paper we present a comparitive dynamic which may be mapped on to other similar comparitive studies. Our results will be of interest in professionals and academics who are involved in the fields of taxation, debt and equity in Eastern Europe and Russia. The schema utilised here may be applied in a similar manner to examine the development of similar economies in Eastern Europe and further afield.

Keywords: financial leverage (leverage); capital structure; corporate taxation; debt financing of projects; effective tax rate; interest coverage ratio; company materiality level; cost of debt; interest coverage level; pooled-regression; between-regression; fixed effects within-regression; random effects within-regression;

JEL: G30, G32 


\section{Introduction}

The principles of capital structure formation have been a primary area of interest in academic research for 50 years. This is because an optimal financial leverage plan may significantly improve the financial performance of a company. Moreover, a patternless formation of financial leverage can be detrimental to the company's value in a volatile economic environment. The methods used to create and maintain one or another form of capital structure are equally important. An unsystematic raising of debt financing results in an uncontrolled growth of interest charge. The latter, in its turn, is often a cause of tangible losses.

The overall purpose of this article is to compare empirical evidence on the capital structure of Polish, Czech, and Russian companies. The objective is achieved by comparing determinants of the capital structure of large companies from Poland and Czech Republic against those of large Russian companies. In the process, it was discovered that taxation exercises a determining effect on the choice of a certain level of leverage.

In order to parse and explicate this discovery, it is necessary to define a set of determinants which should be tested, along with identifying the effective taxation level. For example, if it is found out that at any particular moment (in our case it is once a year) the financial leverage is defined by the effective taxation level for Russian, Polish and Czech companies, one may postulate the existence of a significant macroeconomic factor of influence on the capital structures of the companies in the studied sample.

It should be noted that the idea of such a study is neither new nor unique, as there have been papers published on the capital structure of Russian companies and companies fromEastern Europe. Nevertheless, there are no publications for these countries with as long a time span as fourteen years.

\section{Theoretical Considerations}

More recently, the importance of the capital structure has increased rapidly for large companies performing activities in emerging markets. The reason for such a heightening of interest is high instability in business environments related to political conflicts. Nevertheless, the fundamental principles of capital structure formation are not as volatile as geopolitical relations.

There are two main theories which explain the choice of capital structure by companies: the pecking order hypothesis (DeAngelo, Masulis, 1980; Kim, 1982; Modigliani, 1982) and the tradeoff theory (Nicholas, Stewart, 1984). It was found that the explanatory power of each theory depends strongly on the selection of companies and the method of their study (Graham, 2011; Ivashkovskaya, Solntseva 2010). There is also a lot of research which aligns with the principles of capital structure formation in emerging capital markets which cannot be described by just one of these theories, as it depends largely on the determinants included in the model (Ivashkovskaya, Makarov 2010). This notwithstanding, we do not intend to define which of the two theories is better in general, or which describes in more detail the principles of choice of the financial leverage by Russian, Polish and Czech companies. Our objective is to define whether the effective tax rate in general is a significant determinant in the model of the capital structure choice for the companies from the countries studied in this article. Then we should find out whether it is determinative in the models of such choice.

\section{Research on the Influence of Taxation on Capital Structure}

In 2012 a paper was published which studied the issue of how the changes in the tax legislation in 2001 influenced changes in the capital structure of companies in Croatia (Klapper, Tzioumis, 2012). The particular contribution of this paper was that it studied corporate taxation, as it was the only sphere that changed. This helped to outline the influence of the corporate tax rate on capital structure directly, without the use of any approximate values. In the course of the reforms in Croatia mentioned in that paper, corporate tax rates were decreased, which reduced the level of financial leverage in many companies. As a result of this research, the authors concluded that large companies are almost unresponsive to changes in the tax rate. This accounts for the fact that large companies have access to tax privileges, and therefore they depend little on the corporate tax rate.

Other authors also studied influence of tax rates on the capital structure (Overesch, Voeller, 2010). The most meaningful among them was the set of regressors used to build the model, and a part of those determinants was used in the present research. The regression model comprised the following: company profitability, the share of tangible assets, size, and indicators related to taxes, etc. Finally, the authors of the article defined that the effective tax rate had a positive impact on the financial leverage level.

Apart from the fact that the corporate income tax rate should be included in the model of capital structure formation, it was established that the best choice for this is the effective tax rate (Graham, 1996).

There is also a view that the corporate tax rate is not the factor defining the financial leverage in every instance. To be more accurate, it has been affirmed that one should not only include corporate taxation in such models (Dhalival, Heitzman, Zhen Li, 2005). This is because the capital structure influences the interest payment and dividend payout policy, and consequently affects shareholders' benefits. As such, the shareholders may influence managers in order to maximise their own earnings, especially if the managers pay out dividends readily. It is necessary to include an individual tax rate in the model in addition to the corporate tax rate, if possible. 


\section{Research on the Influence of Other Determinants of the Capital Structure}

The availability of debt financing for projects has an influence on the capital structure formation just as much as other factors (Faulkender, Petersen, 2004). Availability of debt financing entails that a company is listed on the stock market and has access to the bond market, and that a rating agency has rated the company. The abovementioned article discovered that if a company has access to the open market, then its financial leverage (debt-to-asset ratio) exceeded by $35 \%$ the financial leverage of the companies which borrowed only from the local banking system.

Credit rating is not the only factor which influences the capital structure of a company. A certain level of the credit rating is of particular importance. If a company has a "bordering" rating (for example, $\mathrm{AA}+$ or $\mathrm{BB}-$ ) it generally tries to maintain a stable level of financial leverage. On the other hand, if a company has a "median" rating (for example, AA or BBB) it tends to be actively involved in the change of its financial leverage because in this case even if the leverage grows (or reduces) the company credit significantly, the rating will just transform into the bordering figure (Kisgen, 2006).

If the cost of debt decreases significantly, we may observe a change in company capital structure as follows. The company increases the debt amount not just for project financing, but for the redemption of its own stock as well (Chevalier, 1995). The cost of debt may be more than just a factor influencing choice of the capital structure which the company should maintain. It is not uncommon that due to whatever limitations, a company sets its capital structure in some order, and then tries to change the sources of its debt financing rapidly in order to minimize expenses (Koyama, 1993).

The next important factor which influences capital structure is company size. Some researchers have discovered that the debt amount of a company correlates positively to its size (a big company implies a predominance of fixed assets in the assets category, and consequently, the existence of a reliable security), except for the cases when a company has just started its operations. The latter case accounts for the fact that very often a company has not enough money to start its business, and therefore debt financing may be raised even if there is no sufficient amount of fixed assets (Kurshev, Strebulaev, 2005).

The tax legislation shows the procedure of capital structure formation from another point of view. The "tax shield" concept comprises several strategies of choice for the format of financial leverage for corporations.Companies invariable perform a continuous search for their optimal financial leverage arrangement, walking a delicate line between the risk of default and the benefits of tax saving (Auerbach, 1985). For example, there is a popular opinion that introducing a progressive taxation encourages growth of the debt amount in large companies (Miller, 1977).

Analysis of a selection of Dutch companies showed that such characteristics as company size, share of fixed assets in the assets structure, and assets earning power each have a positive impact on financial leverage (Chen, 1998).

\section{Methodology and Hypotheses}

We perform a regression analysis in this research, and interpret the results using theoretical knowledge, as articulated in the academic literature. The dependent variable in all tested regressions is financial leverage, which is calculated as the ratio of the sum of short-term and longterm debts to the sum of short-term and long-term assets, as this precise set of input values was uploaded from the Bloomberg database. This indicator is equivalent to the ratio of aggregate debt to aggregate assets, but it is not the only manner of calculation. For example, leverage is also sometimes calculated as the ratio of aggregate debt to equity capital. However, to be more definite, the first approach was chosen.

The tax level (effective tax rate) is the first applied regressor, which will be the key variable in the tested hypotheses. This parameter was calculated as the ratio of income tax payments for a period to EBT (earnings before taxes). In order to test the hypotheses set forth below, some variables were created: interest coverage ratio (the ratio of earnings before interests and taxes to interest expenses), the level of company tangibility (the ratio of long-term assets to the company's aggregate assets), cost of debt (the ratio of interest expenses to aggregate debt). As for the company's tangibility level, it should be added that it is not entirely correct to simply consider the companies' long-term assets as fixed assets which may be put at stake (in the form of pledge, or collateral) to aid the cause of raising debt capital. Nevertheless, taking into account the absence of information concerning the amount of fixed assets of each company, the ratio of long-term assets to aggregate assets may be an approximant when calculating the value of the company. Apart from the created variables, the model also comprises a variable uploaded beforehand - ROA (return on assets). The issue of the value of interest coverage should be also clarified. No research has been found which tests the influence of precisely this factor on the financial leverage. However, we believe that a confirmation of negative dependence between the cost of debt and financial leverage is a sufficient foundation for including interest coverage level into the model of capital structure formation. This is because even if the cost of debt rises significantly, then at a high ratio of interest coverage, a company may go on increasing debt when it needs additional financing.

We will now discuss the hypotheses to be tested in this research. The first hypothesis consists in verifying whether the effective tax rate is a significant factor in the model of the capital structure formation of large companies in Russia, Poland and Czech Republic. Therefore, the first hypothesis is phrased as follows:

H1: the effective tax rate is a significant factor in the models of capital structure formation for large companies in Russia, Poland and Czech Republic 
In case of confirmation of the first hypothesis it seems appropriate to test the second hypothesis, which is articulated as follows:

$\mathrm{H} 2$ : the effective tax rate is a significant factor in the models of the capital structure formation of large companies in Russia, Poland and Czech Republic, if among other factors introduced in the regression equations there is no other factor which at the same time: 1) is significant in regression equations for each of the three countries and 2) is more significant than the effective tax rate in the majority of regression equations.

\section{Data and Model Specification}

Data regarding various indicators of large nonfinancial companies were selected for this research: Russia (50 companies), Poland (9 companies) and Czech Republic (10 companies). These are public companies and have the following indexes: MICEX (Russia), WIG-POLAND (Poland) and PX Index (Czech Republic). These figures are exclusive of companies which were omitted from the selection as their available data contained too many omissions in the downloaded parameters. Russia was chosen as the 'main' country due to the amount of available information, and in order to explicate further the results of its macroeconomic policies. The main criterion for choosing the other two countries for analysis was the fact that they and Russia have long existed in the environment of the command economy and then virtually simultaneously changed over to the market economy. This particular fact confers the possibility of testing the significance of influence of taxation on the capital structure as one of few factors which shows radically different values in these three countries. The following indicators were uploaded from the Bloomberg database for the period of 2001 to 2017 concerning companies from the abovementioned countries: short-term debt, long-term debt, current assets, non-current assets, income tax, EBIT, interest expenses, ROA, market capitalisation.

Indicators such as leverage, tax level, interest coverage ratio, tangibility and cost of debt were also calculated. The selections for Poland and Czech Republic were balanced in order to have values on all indicators for the whole studied period. This allows for the surpassing of the assessments displacement of regression coefficients. Nevertheless, it was impossible to perform this balancing completely for Russian companies because it would have resulted in a significant reduction of the selection. Several indicators for each year are missing from the data for the 50 companies remaining for analysis. In order to make the conducted analysis justifiable, the set of companies for each country was unchanged for the whole analyzed period.

In order to build regressions, either specific values, or natural logarithms of base parameters were used. Thus, the following type of model was tested:

LEVERAGE $_{\mathrm{t}}=\mathrm{b}_{1} \cdot \mathrm{LN}_{-}$TAX_LEVEL $\mathrm{t}-1+\mathrm{b}_{2} \cdot \mathrm{LN} \_$CAPITAL $_{\mathrm{t}-1}+\mathrm{b}_{3} \cdot$ INT_COVERAGE $_{\mathrm{t}-1}+\mathrm{b}_{4} \cdot$ TANGIBILITY $_{\mathrm{t}-1}+$ $\mathrm{b}_{5} \cdot \mathrm{ROA}_{\mathrm{t}-1}+\mathrm{b}_{6} \cdot$ COST_OF_DEBT $\mathrm{t}-1$, where LEVERAGE - financial leverage; LN_TAX_LEVEL - natural logarithm of the effective tax rate; LN_CAP-

ITAL - natural logarithm of the capital (assets) sum; INT_COVERAGE - interest coverage ratio; TANGIBILITY - level of a company materiality; ROA - return on assets, COST_OF_DEBT - cost of debt; $b_{i}$ - regression coefficients.

In this regression the dependent variable is taken from one period and all regressors are taken from the previous period, i.e. with a one-year lag. This is done on the basis of an assumption that the current value was defined in an optimal way as a response to the results of analysis of the previous period's indicators. Inclusion of the current period repressors may produce the endogeneity problem, because the current value of repressors is to a great extent defined by the value of financial leverage in the current period.

Instead of the lagged variables of the effective tax rate and capitalization, their natural logarithms were taken. In case of capitalization it was done in order to level down the difference in the size of companies. In spite of the fact that only large companies which keep accounts in accordance with International Financial Reporting Standards were chosen for the analysis, the difference in the size is still significant (the selected companies' capitalization varies from tens of millions to tens of billions of US dollars). The logarithm of the effective tax rate was taken merely because in the data pretesting, the quality of regressions was in all cases higher when using precisely the naturally logged value of the effective tax rate.

In accordance with the most widespread provisions of the papers mentioned in the literature review, the following dependencies of capital structure on the chosen factors are expected: the financial leverage will have a negative dependence on the cost of debt and return on assets, while the dependence on the tax level, market capitalization, amount of interest coverage and the share of fixed assets in the company assets will be positive.

\section{Russian Companies}

We built four types of regressions:

1) Pooled-regression - this model does not take into consideration either temporal effects, or individual effects;

2) Between-regression - this model does not take into account the temporal effect (in this regression the values of indicators for individuals are timeaveraged);

3) Fixed effects within-regression (FE) - this regression is built in the deviations of indicators from the timeaveraged indicator for each item. At the same time it is presumed that each company adds its individual effect as a constant to the main constant of the regression;

4) Random effects within-regression (RE) - the essence of this model consists in the fact that, unlike in the FE model, the individual effect is in the form of an error instead of a constant. 
Table 1. The final regression for the selection of Russian companies

\begin{tabular}{|c|c|c|c|c|c|c|}
\hline LEVERAGE & Coaf. & Std.Err & $\mathbf{t}$ & $\mathbf{P}>|\mathbf{t}|$ & \multicolumn{2}{|c|}{ ( $95 \%$ Conf. Interval ) } \\
\hline 1_LN_TAX_LEVEL & .0490474 & .0106026 & 2.85 & 0,008 & -.463206 & 0.317742 \\
\hline 1_LN_CAPITAL & .0374842 & .0168394 & 2.22 & 0,031 & .0033063 & 0.414621 \\
\hline 1_INT_COVERAGE & $-6.73 e-07$ & $1.83-\mathrm{e} 07$ & -3.65 & 0,001 & $-1.03 \mathrm{e} 06$ & $-3.01 e-07$ \\
\hline 1_ROA & -.003131 & .0008037 & -3.90 & 0,000 & -.0047308 & -.0015112 \\
\hline _cona & -.0574146 & .136484 & -0.37 & 0,715 & -.3727873 & .2379582 \\
\hline sigma_u & .15433161 & & & & & \\
\hline sigma_e & .08738946 & & & & & \\
\hline rho & .75721261 & (fraction $\mathrm{o}$ & ance $\mathrm{du}$ & & & \\
\hline
\end{tabular}

Source: calculated by the author.

On the basis of the results of F-test we have to opt out of the pooled-model in favour of the FE model. However, the Breusch-Pagan test shows that the RE model is the most preferable one.

Then we have to make our choice between FE and RE models. However, before that, one can notice that in both models the variables 1_COST_OF_DEBT and 1_TANGIBILITY are not significant even at the $10 \%$ level of admissible error. Consequently, we will exclude these variables from the analysis when making further comparison of FE and RE models.

The insignificance of the variable 1_COST_OF_DEBT may be accounted for by the fact that in Russia, the cost of raising debt will be cheaper in the majority of cases than that of raising additional equity capital. Therefore, one is almost always ready to pay the quoted price for the use of the debt, because a decision on the issue of debt securities or the obtaining of credit is defined by other factors. As for the variable 1_TANGIBILITY, its insignificance may be accounted for by the fact that Russian financial directors do not adequately take into consideration the existence of pledge assets when they take a decision on a change of the financial leverage.

If we consider these two factors together, we may make a more general conclusion that Russian corporations take decisions on a change of the financial leverage on the basis of the company's needs in additional financing and not on the basis of the company's ability to have a debt load with little risk.

Now, we will build the regression models and compare FE and $\mathrm{RE}$ regressions to the new set of variables.

Then we conduct the Hausman test. As a result of this test we find out that if we choose RE model the quality of the results will go down, therefore we should choose FE model.We shall also verify our regression for heteroscedasticity and autocorrelation. To verify the first problem, we apply the Wald test. On the basis of the results of this test one can make a conclusion on existence of heteroscedasticity. Consequently, it is necessary to apply a robust estimator of the regression coefficients when building the regression.

In order to test autocorrelation we will apply the Wooldridge test. The test showed that autocorrelation exists. Nevertheless, we cannot weaken its influence within this selection for two reasons. First, for the xtreg function, the method of weakening of autocorrelation using only clusterisation is applied. Second, our selection is not large enough to divide it into clusters.

The final regression for the selection of Russian companies is presented in Table. 1 .

\section{Coefficient Interpretation}

LN_TAX_LEVEL: The sign is positive for this variable, and as expected by the hypotheses, it accords with opinions expressed in existing research. It appears that the fact that a growth in paid taxes urges financial directors to increase financial leverage for the purpose of tax saving is applicable to Russian companies.

LN_CAPITAL: The sign is positive for this variable, and it accords with the assumptions made before conducting the analysis. This accounts for the fact that companies with high capitalisation feel more confident in the capital market and it is easier for them to come to an agreement concerning favourable terms of debt raising, and as a consequence, their financial leverage is bigger.

INT_COVERAGE: The coefficient significance at interest coverage is at the bordering-significance level (error probability 0.136). Nevertheless, this parameter was not excluded from the regression. It is important to note that the sign for this variable was in contrast to the sign expected in accordance with the hypothesis. This may be explained as follows: if a company has a very high interest coverage, later it will also have a high pretax profit as well 
as net profit. It follows that in most cases the company has enough money to satisfy its needs and it does not need to raise debts.

ROA: The sign is negative for this coefficient, and this confirms our hypothesis, and validated the following articulation: if return on assets is high, the net profit flows are enough to finance the company needs, and there is no need to raise debt capital.

\section{Polish companies}

The results of building of each separate regression are shown in Appendix 3. Below is a summary table of regression coefficients indicating the level of significance of each of them.

We failed to build the between-regression because the selection is not large enough. On the basis of the results of the F-test we have to opt out of the pooled-model in favour of FE.

The Breusch-Pagan test helps to compare the pooled model and RE model.

As we see, this hypothesis is not rejected, so we have to verify the fact that the FE model shows better accuracy results than the RE model. In this case it is not important for us which model is better: the pooled or the RE model. But before that one can notice that in both models the variables 1_TANGIBILITY and 1_ROA are not significant even at the $10 \%$ level of admissible error for the selection of Polish companies. Consequently, we will exclude these variables from the analysis when making further comparison of FE and RE models.

Insignificance of the variable 1_ROA may be accounted for by the fact that in Poland the return on assets in the majority of cases does not serve as a guideline for changing the financial leverage. Therefore, the decision on raising debt financing will be defined by the needs of financing in general, and not by the way it will influence the overall benefit from company assets. As for the variable 1_TANGIBILITY, its insignificance may be accounted for by the fact that the existence of pledge assets does not play a critical role in defining the possibility of an increase in the financial leverage because it is always possible to select a set of terms at which the debt financing will be raised.

If we consider these two factors together, we may make a more general conclusion that Polish corporations take decisions on changes of financial leverage on the basis of the company's need for additional financing, and not on the company's ability to have a debt load with little risk and effective efficiency.

At this stage, we will examine regression models in order to compare $\mathrm{FE}$ and $\mathrm{RE}$ regressions to the new set of variables. Then we conduct the Hausman test. As a result of this test, we find out that simplification of our model from the FE to the RE model need not impair its quality. Nevertheless, we will choose the FE model because it comprises more significant factors. However, the coefficient for the interest coverage variable remains substantially insignificant, therefore it is excluded from the final model.

We will also seek to verify our regression for heteroscedasticity and autocorrelation. To verify the first problem we apply the Wald test.

On the basis of the results of this test one can make a conclusion on presence of heteroscedasticity. Consequently, it is necessary to apply the robust estimator of the regression coefficients when building the regression.

In order to test autocorrelation, we will apply the Wooldridge test. The test showed that autocorrelation exists, though there is a $10 \%$ probability of its absence. Nevertheless, we cannot weaken its influence within this selection for two reasons. First, for the xtreg function, the method for the weakening of autocorrelation using just clusterisation is applied. Second, our selection is not large enough to divide it into clusters (table 2).

Table 2. The final regression for the selection of Polish companies

\begin{tabular}{|c|c|c|c|c|c|c|}
\hline LEVERAGE & Coaf. & Std.Err & $\mathbf{t}$ & $P>|t|$ & \multicolumn{2}{|c|}{ ( $95 \%$ Conf. Interval ) } \\
\hline 1_LN_TAX_LEVEL & .0553259 & .0152596 & 3.63 & 0,015 & 0.0160998 & .094332 \\
\hline 1_LN_CAPITAL & 0.27151 & .0123826 & 2.16 & 0,083 & -.0051937 & .0594937 \\
\hline 1_COST_OF_DEBT & -.0131937 & .0007042 & -18.74 & 0,000 & -.015004 & -.0113835 \\
\hline _cona & .0681903 & 0933299 & 0.73 & 0,499 & -.1722355 & .3086173 \\
\hline sigma_u & .12327546 & & & & & \\
\hline sigma_e & .07789899 & & & & & \\
\hline rho & .71463785 & (fraction & nce due & & & \\
\hline
\end{tabular}

Source: calculated by the author. 


\section{Coefficient Interpretation}

LN_TAX_LEVEL: The sign is positive for this variable, and as expected by the hypotheses, it accords with the opinion expressed in some previous research. It appears that the fact that a growth of paid taxes urges financial directors to increase financial leverage for the purpose of saving on tax expenditure is applicable to Polish companies.

LN_CAPITAL: This sign is positive for this variable, and this accords with the assumptions made before conducting the analysis. This accounts for the fact that companies with high capitalisation feel more confident in the capital market and it is easier for them to come to an agreement concerning favourable terms of debt raising. As a consequence, their financial leverage is bigger.

COST_OF_DEBT: The sign is negative for this variable, and this accords with our hypotheses that the more expensive the raising of debt capital, the less benefit available from its use in the form of a "tax shield" and additional benefit from high income projects in which such debt capital could be invested.

\section{Czech Companies}

The construction of each separate regression is shown in Appendix 5. See below for a summary table of regression coefficients indicating the level of significance of each of them. Construction of the between-regression in this case yielded the most significant results. Therefore, we will first find out which of the three rest models best describes the Czech model of the financial leverage formation, and then we will compare it to the between-model.

In order to compare FE and pooled-models it is sufficient to consider the results of F-test conducted after building the FE-regression. As long as this hypothesis is rejected, we have to opt out of the pooled-model in favour of the FE-model.

The Breusch-Pagan test indicates that the RE model is superior with regard to the accuracy of obtained results compared to the FE model. In this case, it is not important which model is better: the pooled or the RE model. As a result of this test we find that if we choose RE model, the quality of the results will go down, and therefore we should choose FE model.

When we find out that the quality of the FE model surpasses the pooled and RE models, we should compare it to the between-model to define the one which best describes the regularity which governs formation of capital structure of Czech corporations. Unfortunately, there is no test which would verify unequivocally which model (betweenor FE) is better in terms of quality. That is why we will choose the model in which the significance of coefficients is higher, i.e. the between-model.

Next, we will exclude insignificant regressors from the list of regressors (in particular, ROA). It is impossible to verify our regression for heteroscedasticity due to the absence of software packages which assist in conducting such analyses on between-models. In order to test autocorrelation, we will apply the Wooldridge test. The test indicates that autocorrelation exists. Nevertheless, we cannot weaken its influence within this selection for two reasons. First, for the xtreg function, the method of the weakening of autocorrelation using just clusterisation is applied. Second, our selection is not large enough to divide it into clusters.

The final regression for the selection of Czech companies is presented in Table 3.

Table 3. The final regression for the selection of Czech companies

\begin{tabular}{|c|c|c|c|c|c|c|}
\hline LEVERAGE & Coaf. & Std.Err & $\mathbf{t}$ & $\mathbf{P}>|\mathbf{t}|$ & \multicolumn{2}{|c|}{ ( $95 \%$ Conf. Interval ) } \\
\hline 1_LN_TAX_LEVEL & 2.765464 & .9243151 & 2.99 & 0,04 & 1991539 & 5.331774 \\
\hline 1_LN_CAPITAL & -.9426263 & .4359327 & -2.16 & 0,097 & -2.15297 & .267717 \\
\hline 1_INT_COVERAGE & 0.131958 & .0063441 & 2.8 & 0,106 & -.0044183 & 0.308098 \\
\hline 1_TANGIBILITY & .0311059 & .0087257 & 5.86 & 0,004 & .0268795 & .0753323 \\
\hline 1_COST_OF_DEBT & -32.38042 & 13.39622 & -2.43 & 0,072 & -69.77429 & 4.613453 \\
\hline _cona & 14.44437 & 3.588116 & 4.3 & 0,016 & 4.482368 & 24.40678 \\
\hline
\end{tabular}

Source: calculated by the author. 


\section{Coefficient Interpretation}

LN_TAX_LEVEL: The sign is positive for this variable, as expected by the hypotheses, and this accords with some existing research. Thus, the fact that a growth of paid taxes urges financial directors to increase the financial leverage for the purpose of saving on tax expenditure is applicable to Russian companies

LN_CAPITAL: The sign is negative for this variable, and it does not accord with the assumptions made before the analysis. However, this may be accounted for by the fact that companies with high capitalisation have fewer prospects for investment, and therefore they do not need to raise debt capital for any unexpected projects. Such companies calculate all other expenses beforehand, relying on their own money flows.

INT_COVERAGE: The coefficient significance at interest coverage is at the bordering-significance level (error probability 0.106 ). Nevertheless, this parameter was not excluded from the regression. The sign for this variable agreed with the sign expected in accordance with the hypothesis. This may be explained as follows: if a company has a very high level of interest coverage, it has an opportunity to pay for the use of a higher financial leverage with little risk.

TANGIBILITY: The sign is positive for this regressor, and this accords with the assumptions made before conducting the data analysis. Thus, the companies with a bigger amount of fixed assets in their balance can afford to use a higher level of financial leverage.

COST_OF_DEBT: The sign is negative for this variable, and accords with our hypotheses that the more expensive the raising of debt capital, the less the benefit gleaned from its use in the form of a "tax shield", and the less additional benefit gleaned from high income projects in which such debt capital could be invested.

\section{Conclusions}

In this article, we conducted study into the influence of corporate taxation on the financial leverage of large companies in Russia, Poland and Czech Republic. Each of the three countries was studied separately. As a result, we discovered that the effective tax rate of corporate taxation exercises a decisive influence on the choice of a certain level of financial leverage.

In order to verify this idea, we defined a set of determinants which were included in the models of choice of the capital structure of each studied country. Then, these determinants were tested along with the effective taxation level.

Our first result established that the effective tax rate is a significant factor in the models of formation of the capital structure of large companies in Russia, Poland and Czech Republic. It was also found that the effective tax rate is the most important factor in the models of formation of the capital structure of large companiesin Russia, Poland and Czech Republic. This result may be accounted for by the fact that we have not included in our model the factor which could have been more significant than the level of the effective tax rate. Verification of this theory could be illustrated in the form of a trend which would have improved the present paper.

This article established that the capital structure of large companies in Russia, Poland and Czech Republic are dependent on the level of corporate taxation in each country, and defined a set of additional determinants for the models of choice of the capital structure for each of these countries. We consider that the primary result of this paper is an advance in understanding of specific aspects of influence of the corporate taxation on the capital structure of companies in Russia, Poland and Czech Republic.

\section{References}

1. Ивашковская И.В., Макаров П.В. Действуют ли классические концепции выбора структуры капитала на развивающихся рынках? Эмпирический анализ компаний Восточной и Центральной Европы. Электронный журнал «Корпоративные финансы», 2010,№ 3, с. 47-62.

2. Auerbach A.J., "Real Determinants of Corporate Leverage”, 1985.

3. Chen L., "The determinants of capital structure: the evidence from the Dutch panel data”, 1998.

4. Chevalier A.J., "Capital Structure and ProductMarket Competition: Empirical Evidence from the Supermarket Industry", 1995.

5. DeAngelo H. et al., "How Stable Are Corporate Capital Structures?”, 2012.

6. DeAngelo H., Masulis R. Optimal Capital Structure under Corporate and Personal Taxation. Journal of Financial Economics, 1980, Vol. 8, p. 3-29.

7. Desai M.A, Foley C.F., Hines J.R., A Multinational Perspective on Capital Structure Choice and Internal Capital Markets. The Journal of Finance, 2004, Vol. 59.

8. Dhalival D., Heitzman S., Zhen Li O., “Taxes, leverage, and the cost of equity capital”, 2005.

9. Faulkender M. and Peterson M., "Does the Source of Capital Affect Capital Structure?”, 2004.

10. Fischer O.E. et al., "Dynamic Capital Structure Choice: Theory and Tests", 1989.

11. Graham J. Debt and the marginal tax rate. J. Fin. Econ., 1996, Vol. 41, p. 41-73.

12. Graham J. Proxies for the marginal tax rate. J. Fin. Econ., 1996, Vol. 42, p.187-221.

13. Graham J., "A Review of Empirical Capital Structure. Research and Directions for the Future", 2011. 
14. Huizinga H., Laeven L., Nicodeme G. Capital Structure and International Debt Shifting. J. Financ. Econ., 2008, Vol. 88, p.80-118.

15. Kayhana A, Titman S. Firms' histories and their capital structures. J. Financ. Econ., 2007, Vol. 83, p. $1-32$.

16. Kim E.H. Miller's Equilibrium, Shareholder Leverage Clienteles, and Optimal Capital Structure. Journal of Finance, 1982, Vol. 37, p. 301-323.

17. Kisgen J.D., "Credit Ratings and Capital Structure”, 2006.

18. Klapper L., Tzioumis K., Taxation and Capital Structure: Evidence from a Transition Economy. Finanz Archiv:Public Finance Analysis, 2012,Vol. 68, p. 165-190.

19. Koyama K., "Corporate Financial Policy and the Cost of Capital”, 1993.

20. Kurshev A. and Strebulaev I.A., "Firm Size and Capital Structure”, 2005.

21. Miller M., "Debt and Taxes". J. Finance, 1977, Vol. 32, p. 261-275.

22. Modigliani F.F., Miller M.H. Corporation Income Taxes and the Cost of Capital: A Correction. American Economic Review, 1963, Vol. 53, p. 433-443.

23. Modigliani, F. Debt, Dividend Policy, Taxes, Inflation, and Market Valuation. Journal of Finance, 1982, Vol. 37, p. 255-273.
24. Myers C.S., Majluf S.N. Corporate financing and investment decision when firms have information that investors do not have. Journal of Financial Economics, 1984, Vol. 13, p. 187-221.

25. Nini G, Smith D, Sufi A., "Creditor control rights and firm investment policy”, 2009.

26. Overesch M., Voeller D. The Impact of Personal and Corporate Taxation on Capital Structure Choices. Finanz Archiv: Public Finance Analysis 2010, Vol.66, p. 263-294.

27. Rampini A, Viswanathan S., "Collateral, risk management and the distribution of debt capacity", 2010.

28. Thiess B., Overesch M., Schreiber U., Wamser G., Taxation and Capital Structure Choice - Evidence from a Panel of German Multinationals. Economics Letters, 2009, Vol. 105, p. 309-311.

29. Majluf, Nicholas S. and Stewart C. Myers. Corporate Financing and Investment Decisions When Firms Have Information That Investors Do Not Have, Journal of Financial Economics, Vol. 13, No. 2, 1984 , pp. $187-221$

30. Ivashkovskaya, I., Solntseva, M. (2010) «The Capital Structure of Russian Companies: Testing Tradeoff Theory Versus Pecking Order Theory», Journal of Corporate Finance Research / Kорпоративные Финансы | ISSN: 2073-0438, 1(2), сc. 17-31. doi: 10.17323/j.jcfr.2073-0438.1.2.2007.17-31. 